\title{
Clinical and Organizational Content of Clinical Pathways for Digestive Surgery: A Systematic Review
}

\author{
L. Lemmens ${ }^{a} \quad$ R. van Zelm ${ }^{c} \quad$ I. Borel Rinkes ${ }^{b} \quad$ R. van Hillegersberg ${ }^{b}$ \\ H. Kerkkamp ${ }^{d}$ \\ Departments of a Perioperative and Emergency Care, and 'burgery, University Medical Center Utrecht, Utrecht, \\ ${ }^{\mathrm{C}} \mathrm{Q}$-Consult Business Consultants, Arnhem, and ${ }^{\mathrm{d}}$ Atrium Medical Center, Heerlen, The Netherlands
}

\section{Key Words}

Digestive tract surgery, outcome $\cdot$ Gastrointestinal cancer .

Digestive surgery, clinical pathways

\begin{abstract}
Background/Aims: Oncology surgery of the gastrointestinal tract is complex and infamous for its high complication rates. One of the methods for implementing interventions to optimize the patients' condition and to enhance postoperative outcome is the development and implementation of a clinical pathway. The aim of this study was to analyze the content, i.e. the interventions of clinical pathways for digestive surgery and their effects on postoperative outcome measures. Methods: We performed a systematic review to study clinical pathways in hospital care for adult patients undergoing elective surgery of the stomach, esophagus, pancreas, liver, colon or rectum. The MEDLINE, EMBASE and CINAHL literature databases were searched. Results: The most common interventions in the clinical pathways in this review were defined in the pre- and postoperative phase and included: nutritional management, pain management, mobilization, education and discharge planning. The primary aim of these interventions was to enhance postoperative recovery. Conclusion: Clinical pathways for digestive surgery con-
\end{abstract}

tain specific interventions to improve postoperative outcome. Most of these interventions are in accordance with the Enhanced Recovery After Surgery (ERAS) protocol, which is an evidence-based protocol for care after colon resections. They result in reduced length of stay without compromising other postoperative outcome measures.

Copyright $\odot 2009$ S. Karger AG, Basel

\section{Introduction}

Oncology surgery of the gastrointestinal tract is known for its high complication rates [1-4]. It usually involves extensive and complex surgery. Moreover, patients are often elderly and suffer from comorbidities $[5,6]$. To improve postoperative outcome, interventions are needed to improve the patients' physical condition before and after surgery. Examples of such interventions are embedded in the Enhanced Recovery After Surgery (ERAS) protocol. This protocol defines specific interventions in perioperative care that are meant to improve postoperative outcome for patients undergoing colonic resection [7, 8]. Other examples of interventions are a thorough preoperative screening of the physical condition of patients [9-11] and preoperative therapeutic exercise training programs $[12,13]$.

\section{KARGER}

Fax +4161306 1234 E-Mail karger@karger.ch www.karger.com (c) 2009 S. Karger AG, Basel

0253-4886/09/0262-0091\$26.00/0

Accessible online at:

www.karger.com/dsu
Mrs. L.C. Lemmens, PhD

Centre for Prevention and Health Services

Research, National Institute for Public Health and the Environment, PO Box 1

NL-3720 BA Bilthoven (The Netherlands)

Tel. +31 30274 4016, Fax +31 30274 4407, E-Mail lidwien.lemmens@rivm.nl 
A method for implementing interventions to optimize the patients' physical condition and to enhance postoperative outcome is a clinical pathway. Clinical pathways are implemented in hospital care to increase the quality of care and to reduce hospital stay and costs $[14,15]$. Currently, clinical pathways are also used to increase the quality of care by reducing variations in care, especially for more complex surgery where the postoperative risk of complications is high $[16,17]$. For digestive surgery, clinical pathways become more common as well [18].

The Department of Surgery of the University Medical Center Utrecht is in the process of designing and implementing several clinical pathways for gastrointestinal oncology surgery. The focus of these clinical pathways is on improving the patients' physical condition before and after surgery by implementing specific interventions. A systematic review was performed to study the interventions that are implemented in clinical pathways to improve postoperative outcome for digestive surgery. The aim of this study was to analyze the content of these clinical pathways and their detectable effects on postoperative outcome.

\section{Methods}

\section{Data Sources}

A search was performed for the period January 2000 to November 2006 in three databases: MEDLINE, EMBASE and CINAHL. The following terms were searched: 'clinical pathway' combined with 'gastrointestinal', 'perioperative', 'surgery and RCT', 'surgery and systematic review', 'gastrointestinal and fast track' or 'perioperative and fast track'. All synonyms for these terms were included in the search as well. References had to be in English, German or Dutch.

\section{Study Selection}

All titles and abstracts were individually read by two reviewers (L.L. and R.v.Z.) and each reviewer made a first selection of articles that had to be studied in more detail. The two selections were compared and consensus was reached on the articles of which a full-text version had to be requested for further study.

Selection criteria were the following: (1) Studies had to concern adults undergoing elective surgery of the stomach, esophagus, pancreas, liver, colon or rectum; (2) studies had to concern clinical pathways in hospital care only; (3) studies should describe a clinical pathway implemented by the author or implemented in the hospital of the author, i.e. it should not concern the content of clinical pathways of other authors; (4) studies should give a sufficient description of the content of the clinical pathway; (5) study designs had to be of sufficient quality, that is, studies should have used a comparative design with a conventional care (control) group, and (6) studies had to report at least two of the following outcome measures which are clinically relevant: length of hospital stay, complication rates, re-admission rates or mortality.
All full-text articles were read by one reviewer (L.L.) to decide whether the article described any medical or organizational content of the clinical pathway and whether a comparative study design with sufficient outcome parameters was used. In case of doubt the second reviewer (R.v.Z.) was consulted and consensus was reached. In case of more articles on the same clinical pathway, the article that had a study design with control group and reported the most elaborately on the content was selected in order to prevent duplication of studies in the review.

\section{Data Extraction}

Content of the Clinical Pathway

One reviewer (L.L.) scored all content, defined as interventions, of the clinical pathways described in the included articles and discussed the scores with the second reviewer (R.v.Z.). The content of the clinical pathway was divided into four different phases of the care process. These phases were the preoperative, intraoperative, postoperative and follow-up phases. The preoperative phase refers to the care before surgery, the intraoperative phase is the care during the surgical procedure (including anesthesia), the postoperative phase refers to the phase in the hospital after surgery and the follow-up phase refers to the care after discharge. Furthermore, a distinction was made between medical and organizational interventions of the clinical pathway. The division into the four phases of care and into the medical and organizational content was discussed with a clinician (H.K., an anesthetist and medical manager) to verify the decisions made by the two reviewers. The professionals engaged in the clinical pathway were scored as well.

Outcome of the Clinical Pathway

Firstly it was assessed which type of study designs were used to evaluate the effectiveness of the clinical pathway. Then the reported length of stay, complication rates, re-admissions and mortality were scored by the reviewers. It was also scored if statistically significant differences between the control group (conventional care) and the pathway group were reported.

Analysis

Frequencies and proportions of the interventions defined and of the health professionals involved in the clinical pathways were calculated. Interventions had to be mentioned in at least $10 \%$ of the studied clinical pathways to be included in the counts.

For the reported effects of the clinical pathways we scored the outcome as reported in the studies. Most studies calculated the mean and the standard deviation for their outcome measures. Meta-analysis was considered not appropriate for this body of literature because of the wide variety of study designs, sample sizes, patient populations and interventions.

\section{Results}

\section{Search Results}

Of the 508 publications, 326 were excluded, as the topic did not meet the selection criteria of adult patients undergoing elective digestive surgery (fig. 1). In total, 123 studies had the wrong subject for our purpose, i.e. they 


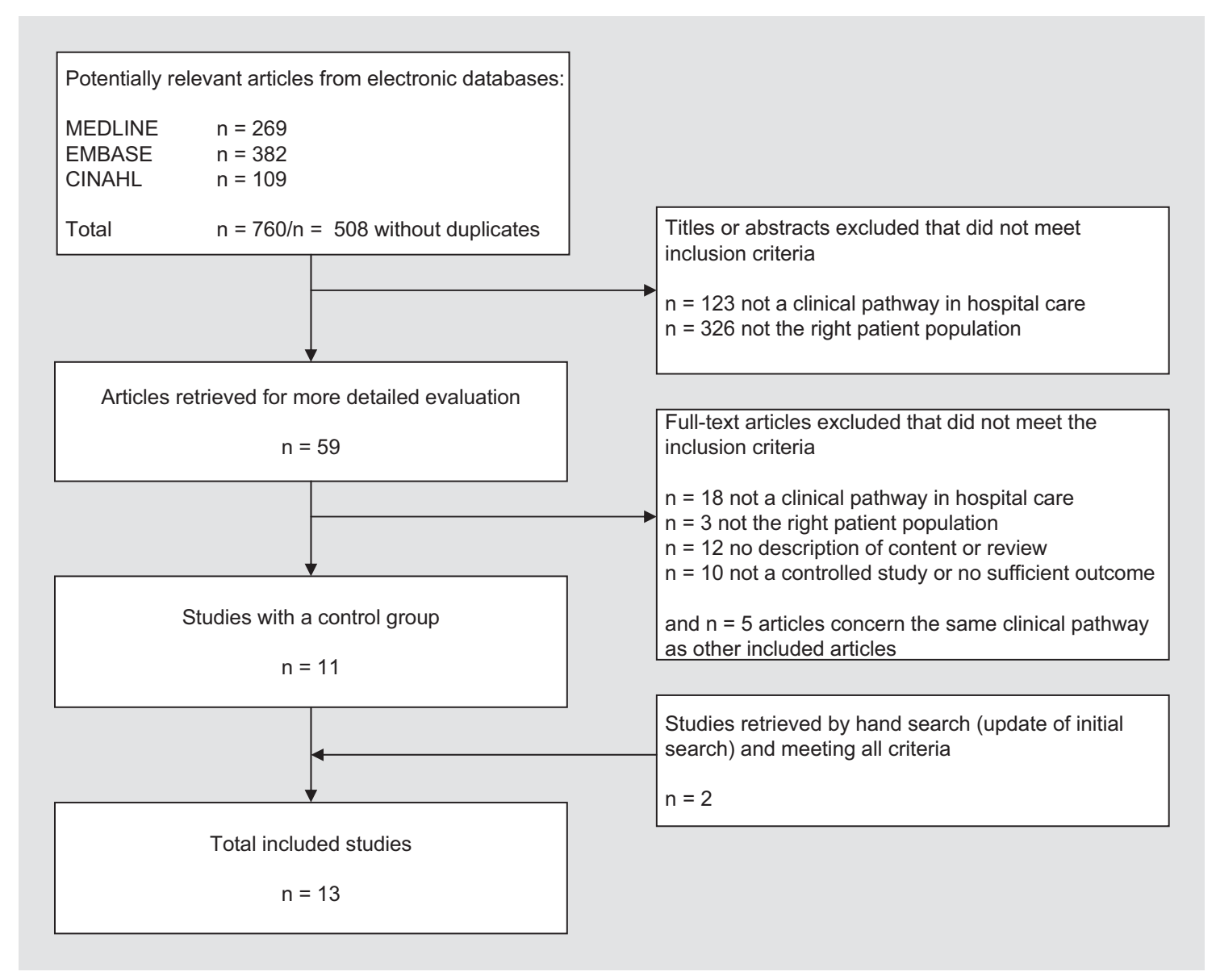

Fig. 1. Systematic review flow diagram.

focused on clinical pathways in a biological or pharmacological sense or on a diagnostic or therapeutic treatment. Subsequently, 59 articles of the 508 were selected and requested full-text for further study.

\section{Sample of Articles}

In total 13 articles were deemed suitable for this review on the specific content of clinical pathways for digestive surgery (fig. 1) [19-31]. Seven (54\%) of the 13 articles concerned studies about the evaluation of clinical pathways in the USA, 2 (15\%) Germany, 2 (15\%) Japan, 1 (8\%) concerned Denmark, and 1 (8\%) concerned Singapore.

In the 13 articles, 13 clinical pathways were evaluated, that is, each article represented a study on 1 clinical pathway. A total of 7 (54\%) of the studied clinical pathways concerned colonic or colorectal resections, 4 (31\%) pancreatic resections and $2(15 \%)$ gastric resections. Resections were performed for either malignant or inflammatory gastrointestinal diseases.

\section{Phases of the Clinical Pathway}

Eleven $(85 \%)$ of the clinical pathways defined interventions in the preoperative phase and 7 (54\%) in the intraoperative phase. In all of the studied clinical pathways $(100 \%)$ interventions in the postoperative phase were defined. None of the clinical pathways defined interventions in the follow-up phase.

\section{Medical Content of the Clinical Pathway}

Most frequently, defined interventions in the clinical pathways were nutritional management (12 out of 13 (92\%)), pain management $(9(69 \%))$, mobilization (9(69\%)) and education of patients and relatives (7 (54\%); table 1a, first column). Examples of nutritional management are allowing clear fluids till X hours before surgery and early enteral feeding after surgery (table $1 \mathrm{~b}$ ). Pain management mostly concerns the use of epidural catheters and the use of specific pain medication. With regard to mobilization, patients are mobilized on specific time intervals after sur-

Dig Surg 2009;26:91-99 
gery, sometimes as early as the day of surgery. Education of patients and relatives concerns, for example, education about the enhanced recovery program.

With regard to the interventions per phase of the clinical pathway: in the preoperative phase, education of patients and relatives, bowel preparation and premedication were most frequently reported (table 1a). Pain management was most frequently defined as an intervention in the intraoperative phase. Postoperatively, nutritional management, pain management and mobilization were most frequently defined as intervention.

\section{Organizational Content of the Clinical Pathway}

In total, 10 of the 13 clinical pathways defined organizational content. Eight (80\%) of these clinical pathways defined discharge planning as a postoperative organizational intervention. Discharge planning concerned the planning of the day of discharge based on the mean length of stay or ideal length of stay for the specific type of digestive surgery. On this date ( $\mathrm{X}$ days after the surgery) patients should ideally be sent home. In two clinical pathways, discharge planning was even started preoperatively. Other organizational content concerned admission $\mathrm{X}$ days before surgery $(1(10 \%))$, avoidance of ICU admission $(1(10 \%))$, and the use of prewritten orders $(2(20 \%))$.

\section{Reported Outcome}

A variety of study designs was used to evaluate outcome of the clinical pathway (table 2). One randomized controlled trial was found, three controlled clinical trials, two case control studies, one case series and six studies in which measurements were taken in the pre-pathway period (control group) and post-pathway (intervention group). In this last study design, either prospective or retrospective control groups were used to compare the outcome of pathway care with non-pathway care, that is, conventional care.

In 11 studies the patients who were treated according to the clinical pathway showed a statistically significantly shorter length of stay than patients from the conventional care group. In three studies a significant decrease in complication rate was observed and in one a significant decrease in re-admission rate was found. None of the studies showed a negative outcome of care according to the clinical pathway. In two and four studies, respectively, re-admission rates and mortality rates were not reported. With regard to more specific outcome coupled to specific interventions in the clinical pathway, positive effects were found regarding nutritional management (early enteral feeding, 7 out of 10 studies reported positive results) and discharge planning ( 5 of 8 reported a positive effect).

Table 1a. Medical content of the clinical pathways and percentage of clinical pathways that define specific interventions in a specific phase

\begin{tabular}{|c|c|c|c|c|}
\hline Intervention (with an example) & $\begin{array}{l}\text { Total } \\
\mathrm{n}=13\end{array}$ & $\begin{array}{l}\text { Preoperative } \\
\mathrm{n}=11\end{array}$ & $\begin{array}{l}\text { Intraoperative } \\
\mathrm{n}=7\end{array}$ & $\begin{array}{l}\text { Postoperative } \\
\mathrm{n}=13\end{array}$ \\
\hline Nutritional management (see table $1 \mathrm{~b}$ ) & $12(92 \%)$ & $1(9 \%)$ & - & $12(92 \%)$ \\
\hline Pain management (see table $1 \mathrm{~b}$ ) & $9(69 \%)$ & - & $6(86 \%)$ & $6(46 \%)$ \\
\hline Mobilization (see table $1 \mathrm{~b})$ & $9(69 \%)$ & - & - & $9(69 \%)$ \\
\hline Education of patient/relatives & $7(54 \%)$ & $7(64 \%)$ & - & $3(23 \%)$ \\
\hline Management of urinary bladder catheter (removal on day X) & $5(38 \%)$ & - & - & $5(81 \%)$ \\
\hline Drain management (removal on day X) & $5(38 \%)$ & - & - & $5(38 \%)$ \\
\hline Use of nasogastric tubes (removal on day X) & $6(46 \%)$ & - & $1(14 \%)$ & $5(38 \%)$ \\
\hline Laboratory tests (which tests at what time points) & $3(23 \%)$ & $2(18 \%)$ & - & $1(8 \%)$ \\
\hline Use of clinical discharge criteria & $4(31 \%)$ & - & - & $4(31 \%)$ \\
\hline Use of premedication & $3(23 \%)$ & $3(27 \%)$ & - & - \\
\hline Oral bowel cleaning/bowel preparation & $4(31 \%)$ & $4(36 \%)$ & - & - \\
\hline Medication management (use of antibiotics) & $4(31 \%)$ & - & - & $4(31 \%)$ \\
\hline Fluid management (i.v.; restriction of fluids) & $3(23 \%)$ & - & $1(14 \%)$ & $2(15 \%)$ \\
\hline Use of specific anesthesia techniques/medication & $2(15 \%)$ & - & $2(29 \%)$ & - \\
\hline Breathing exercises & $2(15 \%)$ & - & - & $2(15 \%)$ \\
\hline Physiotherapy/physical therapy & $2(15 \%)$ & $1(9 \%)$ & - & $1(8 \%)$ \\
\hline Stoma care/stoma siting & $2(15 \%)$ & $2(18 \%)$ & - & $2(15 \%)$ \\
\hline Use of antiembolism stockings & $2(15 \%)$ & - & $2(29 \%)$ & - \\
\hline EGC (ordering of EGCs) & $2(15 \%)$ & $2(18 \%)$ & - & - \\
\hline
\end{tabular}


Table 1b. Specification of top three of medical content of the clinical pathways

\begin{tabular}{|c|c|c|c|c|c|}
\hline & Type of surgery & $\begin{array}{l}\text { Nutritional management } \\
\mathrm{n}=12\end{array}$ & $\begin{array}{l}\text { Pain management } \\
\mathrm{n}=9\end{array}$ & $\begin{array}{l}\text { Mobilization } \\
\mathrm{n}=9\end{array}$ & $\begin{array}{l}\text { Estimated/ } \\
\text { aimed length } \\
\text { of stay }\end{array}$ \\
\hline $\begin{array}{l}\text { Balcom et al., } \\
2001[19]\end{array}$ & $\begin{array}{l}\text { pancreatico- } \\
\text { duodenectomy }\end{array}$ & - & - & - & - \\
\hline $\begin{array}{l}\text { Basse et al., } 2004[20] \\
\text { (CP also described } \\
\text { in Basse et al., } \\
2002[32])\end{array}$ & $\begin{array}{l}\text { colonic } \\
\text { surgery }\end{array}$ & $\begin{array}{l}\text { POD0: after surgery start } \\
\text { liquids and } 2 \text { protein drinks } \\
\text { POD1: start normal food and } \\
4 \text { protein drinks } \\
\text { POD2: normal oral intake and } \\
4 \text { protein drinks }\end{array}$ & $\begin{array}{l}\text { POD0: thoracic epidural catheter } \\
\text { POD1: epidural with bupivacaine and } \\
\text { morphine add. ibuprofen, bupivacaine } \\
\text { or opioid for breakthrough pain } \\
\text { POD2: removal epidural, oral ibuprofen } \\
\text { and morphine tablets for rescue } \\
\text { analgesia }\end{array}$ & $\begin{array}{l}\text { POD0: } 2 \mathrm{~h} \text { mobilization } \\
\text { POD1: }>8 \text { h mobilization } \\
\text { POD2: full mobilization }\end{array}$ & $48 \mathrm{~h}$ \\
\hline $\begin{array}{l}\text { Delaney et al., } \\
2003 \text { [21] } \\
\text { (CP also described } \\
\text { in Delaney, } \\
2001[33] \text { ) }\end{array}$ & $\begin{array}{l}\text { colorectal } \\
\text { surgery }\end{array}$ & $\begin{array}{l}\text { POD0: after surgery liquids as } \\
\text { desired } \\
\text { POD1: non-carbonated liquids, } \\
\text { offered solid food } \\
\text { in evening if able to tolerate } \\
\text { oral fluids }\end{array}$ & $\begin{array}{l}\text { POD0: intravenous PCA, no epidural } \\
\text { intravenous ketorolac } 30 \mathrm{mg} / 6 \mathrm{~h} \text { if } \\
\text { needed } \\
\text { POD2: PCA removed, oral analgesia }\end{array}$ & $\begin{array}{l}\text { POD0: voluntary walk } \\
\text { POD1: encouraged to walk, } \\
\text { sit on bed between walks, } \\
\text { incentive spirometry }\end{array}$ & - \\
\hline $\begin{array}{l}\text { Hirao et al., } \\
2005 \text { [22] }\end{array}$ & gastrectomy & $\begin{array}{l}\text { patient-controlled diet or diet } \\
\text { according to a schedule, not } \\
\text { specified }\end{array}$ & - & - & 14 days \\
\hline $\begin{array}{l}\text { Hirasaki et al., } \\
2004[23]\end{array}$ & $\begin{array}{l}\text { gastric } \\
\text { dissection }\end{array}$ & $\begin{array}{l}\text { POD0 to POD1: fasting } \\
\text { POD2: start oral intake }\end{array}$ & - & - & 7 days \\
\hline $\begin{array}{l}\text { Kariv et al., } \\
2007[24]\end{array}$ & $\begin{array}{l}\text { ileo-anal } \\
\text { pouch surgery }\end{array}$ & $\begin{array}{l}\text { POD0: oral liquids in evening } \\
\text { POD1: solid food in evening }\end{array}$ & $\begin{array}{l}\text { POD0: no epidural anesthesia or } \\
\text { analgesia; intravenous PCA }\end{array}$ & $\begin{array}{l}\text { POD0: sit in chair and walk } \\
\text { POD1 to POD5: ambulate at } \\
\text { least } 5 \text { times around nursing } \\
\text { floor }\end{array}$ & 5 days \\
\hline $\begin{array}{l}\text { Kennedy et al., } \\
2007[25]\end{array}$ & $\begin{array}{l}\text { pancreatico- } \\
\text { duodenectomy }\end{array}$ & $\begin{array}{l}\text { POD1: start sips of water and } \\
\text { ice chips } \\
\text { POD2: clear liquid diet } \\
\text { POD3: regular diet with } \\
\text { pancreatic enzymes }\end{array}$ & $\begin{array}{l}\text { POD0: no epidural anesthesia or } \\
\text { analgesia; intravenous PCA }\end{array}$ & $\begin{array}{l}\text { POD1: out of bed ambulating } \\
\text { POD6 and POD7: continue to } \\
\text { increase activity levels }\end{array}$ & 6-7 days \\
\hline $\begin{array}{l}\text { Melbert et al., } \\
2002[26]\end{array}$ & $\begin{array}{l}\text { colorectal } \\
\text { surgery }\end{array}$ & $\begin{array}{l}\text { routine early postoperative } \\
\text { feeding, not specified }\end{array}$ & $\begin{array}{l}\text { optimizing pain control with liberal } \\
\text { use of postoperative epidural analgesia, } \\
\text { PCA and NSAIDs }\end{array}$ & $\begin{array}{l}\text { early and frequent } \\
\text { ambulation, not specified }\end{array}$ & - \\
\hline $\begin{array}{l}\text { Porter et al., } \\
2000[27]\end{array}$ & $\begin{array}{l}\text { pancreatico- } \\
\text { duodenectomy }\end{array}$ & not specified & - & - & \\
\hline $\begin{array}{l}\text { Raue et al., 2004 [28] } \\
\text { (CP also described } \\
\text { in Schwenk } \\
\text { et al., 2004 [34], } \\
2006 \text { [35]) }\end{array}$ & $\begin{array}{l}\text { laparoscopic } \\
\text { sigmoidectomy }\end{array}$ & $\begin{array}{l}\text { POD0: after surgery tea, yogurt } \\
\text { POD1 to POD3: regular } \\
\text { hospital food }\end{array}$ & $\begin{array}{l}\text { POD0 to POD1: epidural analgesia } \\
\text { (LA/opioid), parecoxib } 40 \text { mg i.v., avoid } \\
\text { systemic opioids } \\
\text { POD2: remove epidural in morning, } \\
\text { valdecoxib } \\
\text { POD3: oral valdecoxib }\end{array}$ & $\begin{array}{l}\text { POD0: short walk, } 2 \mathrm{~h} \text { in chair } \\
\text { POD1: > } 8 \text { h out of bed } \\
\text { POD2 to POD3: fully } \\
\text { mobilized }\end{array}$ & 3 days \\
\hline $\begin{array}{l}\text { Stephen et al., } \\
2003[29]\end{array}$ & colon resection & $\begin{array}{l}\text { POD1: sips of clear liquids, } \\
\text { excluding carbonated drinks } \\
\text { POD2: unrestricted clear diet }\end{array}$ & $\begin{array}{l}\text { POD0 to POD2: epidural catheter } \\
\text { POD2/3: epidural removed, oral } \\
\text { analgesia }\end{array}$ & $\begin{array}{l}\text { POD0: mobilized to a chair } \\
\text { POD1: ambulated } 3 \text { times/day }\end{array}$ & $2-3$ days \\
\hline $\begin{array}{l}\text { Tan et al., } \\
2005[30]\end{array}$ & $\begin{array}{l}\text { major colorectal } \\
\text { surgery }\end{array}$ & $\begin{array}{l}\text { POD1 to POD2: initiation of } \\
\text { feeds/diet }\end{array}$ & $\begin{array}{l}\text { POD0: postoperative analgesia, not } \\
\text { specified }\end{array}$ & $\begin{array}{l}\text { rapid mobilization } \\
\text { POD1 to POD2: chest and } \\
\text { limb physiotherapy } \\
\text { POD3 to PODX: } \\
\text { physiotherapy and ambulation }\end{array}$ & - \\
\hline $\begin{array}{l}\text { Wichmann et al., } \\
2006 \text { [31] } \\
\text { (CP also described } \\
\text { in Wichmann et al., } \\
2005[36])\end{array}$ & $\begin{array}{l}\text { pancreatic } \\
\text { surgery }\end{array}$ & $\begin{array}{l}\text { POD0: reduced preoperative } \\
\text { fasting, drinks till } 2 \mathrm{~h} \text { before } \\
\text { surgery } \\
\text { POD0: clear fluids } \\
\text { POD3: solid food } \\
\text { POD5: complete enteral nutrition }\end{array}$ & $\begin{array}{l}\text { POD0 to POD2: thoracic epidural } \\
\text { catheter with COX II inhibitors }\end{array}$ & $\begin{array}{l}\text { POD0 to PODX: mobilization } \\
\text { according to schedule, longer } \\
\text { out of bed every day }\end{array}$ & 10 days \\
\hline
\end{tabular}

$\mathrm{CP}=$ Clinical pathway; PCA = patient-controlled analgesia; $\mathrm{POD} 0$ = day of surgery; POD1 = first day after surgery; POD2 = second day after surgery, etc.; - = not reported/unknown. 
Table 2. Outcome of the clinical pathways in the studies $(n=13)$

\begin{tabular}{|c|c|c|c|c|c|c|c|}
\hline Studies & Type of surgery & Study design & $\begin{array}{l}\text { Patients in } \\
\text { control/clinical } \\
\text { pathway group }\end{array}$ & $\begin{array}{l}\text { Decrease in length of stay }{ }^{1} \\
\text { days }\end{array}$ & $\begin{array}{l}\text { Decrease in } \\
\text { com- } \\
\text { plications }^{1}\end{array}$ & $\begin{array}{l}\text { Decrease } \\
\text { in re-admis- } \\
\text { sion rate }^{1}\end{array}$ & $\begin{array}{l}\text { Decrease } \\
\text { in mortal- } \\
\text { ity rate }^{1}\end{array}$ \\
\hline $\begin{array}{l}\text { Basse et al., } \\
2004\end{array}$ & colonic surgery & $\begin{array}{l}\text { pre- and post-pathway measure- } \\
\text { ments, the control consisted of } \\
\text { patients from another hospital }\end{array}$ & $130 / 130$ & $\begin{array}{l}\text { from } 10 \text { to } 3.3 \text { (mean) } \\
\text { from } 8 \text { to } 2 \text { (median) }\end{array}$ & $\begin{array}{l}\text { from } 45 \% \\
\text { to } 25 \%\end{array}$ & n.s. & n.s. \\
\hline $\begin{array}{l}\text { Delaney et al., } \\
2003[21]\end{array}$ & $\begin{array}{l}\text { intestinal or rectal } \\
\text { resection by } \\
\text { laparotomy }\end{array}$ & randomized controlled trial & $33 / 31$ & $\begin{array}{l}\text { from } 7.1 \pm 4.8 \text { to } 5.4 \pm 2.5 \\
\text { (mean } \pm S D)\end{array}$ & n.s & n.s & $\begin{array}{l}\text { not } \\
\text { reported }\end{array}$ \\
\hline $\begin{array}{l}\text { Melbert et al., } \\
2002[26]\end{array}$ & colorectal surgery & $\begin{array}{l}\text { controlled clinical trial, surgeons } \\
\text { decided which patients followed } \\
\text { pathway }\end{array}$ & $122 / 263$ & from 8.2 to 5.5 (mean) & n.s. & n.s. & n.s. \\
\hline $\begin{array}{l}\text { Kariv et al., } \\
2006[24]\end{array}$ & $\begin{array}{l}\text { ileo-anal pouch } \\
\text { surgery }\end{array}$ & case-control study & $97 / 97$ & $\begin{array}{l}\text { from } 5.9 \text { to } 5.0 \text { (mean) } \\
\text { from } 5 \text { to } 4 \text { (median) }\end{array}$ & n.s. & n.s. & n.s. \\
\hline $\begin{array}{l}\text { Raue et al., } \\
2004 \text { [28] }\end{array}$ & $\begin{array}{l}\text { laparoscopic } \\
\text { sigmoidectomy }\end{array}$ & $\begin{array}{l}\text { controlled clinical trial, patients } \\
\text { of one surgeon/department were } \\
\text { assigned to the pathway }\end{array}$ & $29 / 23$ & from 7 to 4 (median) & n.s. & n.s. & n.s. \\
\hline $\begin{array}{l}\text { Stephen et al., } \\
2003 \text { [29] }\end{array}$ & colon resection & $\begin{array}{l}\text { pre- and post-pathway } \\
\text { measurements }\end{array}$ & $52 / 86$ & $\begin{array}{l}\text { from } 6.6 \pm 3.3 \text { to } 3.7 \pm 1.5 \\
\text { (mean } \pm S D)\end{array}$ & n.s. & n.s. & $\begin{array}{l}\text { not } \\
\text { reported }\end{array}$ \\
\hline $\begin{array}{l}\text { Tan et al., } \\
2005[30]\end{array}$ & $\begin{array}{l}\text { major colorectal } \\
\text { surgery }\end{array}$ & $\begin{array}{l}\text { pre- and post-pathway } \\
\text { measurements }\end{array}$ & $204 / 204$ & n.s. & $\begin{array}{l}\text { from } 33 \% \\
\text { to } 20 \%\end{array}$ & $\begin{array}{l}\text { from } 13 \% \\
\text { to } 6 \%\end{array}$ & n.s. \\
\hline $\begin{array}{l}\text { Hirao et al., } \\
2005[22]\end{array}$ & gastrectomy & controlled clinical trial & $50 / 53$ & $\begin{array}{l}\text { from } 21.7 \pm 8.8 \text { to } 18.5 \pm 5.9 \\
(\text { mean } \pm S D)\end{array}$ & n.s. & n.s & n.s. \\
\hline $\begin{array}{l}\text { Hirasaki et al., } \\
2004[23]\end{array}$ & gastric dissection & $\begin{array}{l}\text { pre- and post-pathway } \\
\text { measurements }\end{array}$ & $20 / 23$ & $\begin{array}{l}\text { from } 17.5 \pm 6.9 \text { to } 10.9 \pm 1.9 \\
(\text { mean } \pm S D)\end{array}$ & n.s. & $\begin{array}{l}\text { not } \\
\text { reported }\end{array}$ & $\begin{array}{l}\text { not } \\
\text { reported }\end{array}$ \\
\hline $\begin{array}{l}\text { Balcom et al., } \\
2001[19]\end{array}$ & $\begin{array}{l}\text { pancreatico- } \\
\text { duodenectomy }\end{array}$ & retrospective case series & $201 / 130$ & $\begin{array}{l}\text { from } 16.1 \pm 0.6 \text { to } 9.5 \pm 0.4 \\
(\text { mean } \pm S E) \text { from } 9 \text { to } 6 \\
\text { (median) }\end{array}$ & $\begin{array}{l}\text { from } 21 \% \\
\text { to } 8.5 \%\end{array}$ & n.s. & n.s. \\
\hline $\begin{array}{l}\text { Kennedy } \\
\text { et al., } 2007 \text { [25] }\end{array}$ & $\begin{array}{l}\text { pancreatico- } \\
\text { duodenectomy }\end{array}$ & $\begin{array}{l}\text { pre- and post-pathway } \\
\text { measurements }\end{array}$ & $44 / 91$ & from 13 to 7 (median) & n.s. & n.s. & n.s. \\
\hline $\begin{array}{l}\text { Porter } \\
\text { et al., } 2000 \text { [27] }\end{array}$ & $\begin{array}{l}\text { pancreatico- } \\
\text { duodenectomy }\end{array}$ & $\begin{array}{l}\text { pre- and post-pathway } \\
\text { measurements }\end{array}$ & $68 / 80$ & from 16.4 to 13.5 (mean) & n.s. & n.s. & n.s. \\
\hline $\begin{array}{l}\text { Wichmann } \\
\text { et al., } 2006 \text { [31] }\end{array}$ & pancreatic surgery & case-control study & $12 / 12$ & n.s. & n.s. & $\begin{array}{l}\text { not } \\
\text { reported }\end{array}$ & $\begin{array}{l}\text { not } \\
\text { reported }\end{array}$ \\
\hline
\end{tabular}

n.s. = No significant differences found between groups. ${ }^{1}$ Decrease had to be significant between control and intervention group, $\mathrm{p}<0.05$.

\section{Professionals Involved in the Clinical Pathway}

In $4(31 \%)$ of the studied clinical pathways specific interventions for surgeons were defined. Interventions for surgeons were most frequently defined in the intraoperative phase. Anesthetists were specifically mentioned to have tasks in 3 (23\%) clinical pathways. Other professionals who were mentioned were doctors or physicians, nurses, stoma therapists, physicals therapists, nurse specialists, dieticians, gastrointestinal pathologists, pharmacists and operating room technicians (all mentioned once). In 4 (31\%) of the clinical pathways it was not specified which health professionals were responsible for the interventions that were defined in the clinical pathway.

\section{Discussion}

\section{Selection and Sample of Articles}

Thirteen studies were selected as relevant for this systematic review. 


\section{Phases and Content of the Clinical Pathways}

Most interventions are defined in the pre- and postoperative phase of the clinical pathways. With regard to the medical content of clinical pathways, nutritional management, pain management, mobilization, and education of patients and relatives are most frequently mentioned. These interventions are all components of the ERAS protocol $[7,8]$. This protocol aims to enhance recovery after colonic surgery by implementing specific interventions in the perioperative care. As a matter of fact, most interventions that are defined in the clinical pathways in this review are in accordance with this ERAS protocol.

Discharge planning is most frequently mentioned as an organizational intervention. An early planned discharge can possibly contribute to a decrease in length of stay, as personnel and patients adapt their expectations to it and act accordingly [37-39].

\section{Outcome of the Clinical Pathways}

According to this review the interventions implemented in the clinical pathways can result in a statistically significant decrease in length of stay. In 11 of the 13 studies evaluating clinical pathways (85\%) a statistically significant decrease in length of stay was observed [19-29]. With regard to complication rates, re-admission rates and mortality, in most studies no significant differences [21-29, $31]$ and sometimes positive effects $[19,20,30]$ are observed between the conventional care and pathway groups. It can therefore be argued that patients can be safely treated according to the clinical pathway as the reported decrease in length of stay does not seem to have any adverse effects on the other three outcome measures. Two studies, however, did not report re-admission rates $[23,31]$ and four did not report mortality $[21,23,28,31]$. Consequently, the results of these outcome measures are unclear.

\section{Professionals Involved in the Clinical Pathway}

It is remarkable that surgeons and anesthetists, although mentioned most frequently, are only mentioned to have specific tasks in $4(31 \%)$ and $3(23 \%)$ of the studied pathways, respectively, as they are the main professionals involved in surgical care. However, it is well known that medical doctors want to hold professional autonomy over their surgical and anesthesia techniques and do not want to conform to standard operating procedures [40]. Actually, in only two of the pathways in this review are specific anesthesia techniques defined and in none of the pathways specific surgical techniques. In $4(31 \%)$ of the described clinical pathways it is not specified at all which professionals are involved. However, it can be assumed that the same professionals are involved as those who are frequently mentioned in other pathways.

\section{Limitations}

More than half of the clinical pathways in this review concern colon resections. Furthermore, no sufficient studies on esophagectomy and liver resection were found in this review. This may result in a limited view on the content of clinical pathways for gastrointestinal surgical procedures. However, most interventions in the pathways for colon resections are generic interventions that can be copied to pathways for other types of digestive surgery. Also, the incidence of (malignant) colon diseases is higher than the incidence of gastric, liver, pancreatic or esophageal diseases, so it is likely that more clinical pathways are developed for colon resections [41]. Nevertheless, we think that clinical pathways are a valuable method for improving care for all types of digestive surgeries, and more studies are needed on clinical pathways for gastric, liver, pancreatic or esophageal cancer.

The level of description of the clinical pathways differs between articles. Some articles present complete day-today time task matrices, while other articles only give a brief description of the clinical pathway. It is possible that interventions in clinical pathways are missed because they are not described in literature. However, it is likely that the most essential interventions of a clinical pathway are described by the authors.

Only one RCT was found, this may be due to the complex nature of the intervention, i.e. a clinical pathway with multiple components of care, to be evaluated. The other study designs included in this review can be regarded as phase II studies, that is, as exploratory trials in preparation of more rigorous trials, as described by Campbell et al. [42] and the Medical Research Council (MRC) [43]. Rigorous study designs to evaluate complex interventions are not only randomized controlled trials but also clustered randomized trial as proposed by Campbell et al. [42] and the Medical Research Council [43, 44]. As no such trials are yet available on clinical pathways for gastrointestinal surgery, we decided to include other study designs in our review. The outcome described in this review should therefore be regarded as indicative for the positive results that can be achieved with clinical pathways for gastrointestinal surgery.

None of the 13 studies report negative effects of the clinical pathway. However, this may be due to a publication bias: studies with positive results are more likely to be published than studies with negative results. 


\section{Conclusions}

Most clinical pathways found in this review concerned colorectal surgery. Although other types of digestive cancer are less common, clinical pathways could be a valuable tool to improve the perioperative care for these patient groups as well. Most commonly, interventions in clinical pathways for digestive surgery are defined in the pre- and postoperative phase and include: nutritional management, pain management, mobilization, education and discharge planning. The aim of these interventions is to enhance postoperative recovery and they are mainly based on the ERAS protocol. Evaluations of the clinical pathways show that a decrease in length of stay is observed without compromising other postoperative outcome measures. However, more rigorous study designs are needed to rule out adverse effects completely. In general, surgeons and anesthetists are mentioned the most often as involved disciplines in the studied clinical pathways. It seems necessary to involve these groups in the development and implementation of clinical pathways.

\section{Acknowledgement}

We acknowledge the Order of Medical Specialists who financially supported this study. The funding source played no role in the design, execution and analysis of this study.

\section{References}

-1 Abdalla EK, Ribero D, Pawlik TM, Zorzi D, Curley SA, Muratore A, Andres A, Mentha G, Capussotti L, Vauthey JN: Resection of hepatic colorectal metastases involving the caudate lobe: perioperative outcome and survival. J Gastrointest Surg 2007;11:66-72.

$\checkmark 2$ Dagher I, Proske JM, Carloni A, Richa H, Tranchart H, Franco D: Laparoscopic liver resection: results for 70 patients. Surg Endosc 2007;21:619-624.

>3 DeOliveira ML, Winter JM, Schafer M, Cunningham SC, Cameron JL, Yeo CJ, Clavien PA: Assessment of complications after pancreatic surgery: a novel grading system applied to 633 patients undergoing pancreaticoduodenectomy. Ann Surg 2006;244: 931-937.

4 Law S, Wong KH, Kwok KF, Chu KM, Wong $\mathrm{J}$ : Predictive factors for postoperative pulmonary complications and mortality after esophagectomy for cancer. Ann Surg 2004; 240:791-800.

5 Audisio RA, Ramesh H, Longo WE, Zbar AP, Pope D: Preoperative assessment of surgical risk in oncogeriatric patients. Oncologist 2005; 10:262-268

6 Ramesh HS, Jain S, Audisio RA: Implications of aging in surgical oncology. Cancer J 2005;11:488-494.

-7 Fearon KC, Ljungqvist O, Von Meyenfeldt M, Revhaug A, Dejong CH, Lassen K, Nygren J, Hausel J, Soop M, Andersen J, Kehlet H: Enhanced recovery after surgery: a consensus review of clinical care for patients undergoing colonic resection. Clin Nutr 2005;24: 466-477.

$\checkmark 8$ Kehlet H, Wilmore DW: Multimodal strategies to improve surgical outcome. Am J Surg 2002;183:630-641.

-9 Lew E, Pavlin DJ, Amundsen L: Outpatient preanaesthesia evaluation clinics. Singapore Med J 2004;45:509-516.
10 Pollard JB, Garnerin P, Dalman RL: Use of outpatient preoperative evaluation to decrease length of stay for vascular surgery. Anesth Analg 1997;85:1307-1311.

-11 Van Klei WA, Moons KG, Rutten CL Schuurhuis A, Knape JT, Kalkman CJ, Grobbee DE: The effect of outpatient preoperative evaluation of hospital inpatients on cancellation of surgery and length of hospital stay. Anesth Analg 2002;94:644-649.

12 Dronkers JJ, Veldman A, Hoberg E, Van der Waal C, Van Meeteren NLU: Prevention of pulmonary complications after upper abdominal surgery by preoperative intensive inspiratory muscle training: a randomized controlled pilot study. Clin Rehabil 2008;22: 134-142.

$>13$ Hulzebos EH, Helders PJ, Favié NJ, de Bie RA, Brutel de la Riviere A, van Meeteren NL: Preoperative intensive inspiratory muscle training to prevent postoperative pulmonary complications in high-risk patients undergoing CABG surgery: a randomized clinical trial. JAMA 2006;296:1851-1857.

14 Coffey RJ, Richards JS, Remmert CS, LeRoy SS, Schoville RR, Baldwin PJ: An introduction to critical paths. Qual Manag Health Care 1992;1:45-54.

$\checkmark 15$ Pearson SD, Goulart-Fisher D, Lee TH: Critical pathways as a strategy for improving care: problems and potential. Ann Intern Med 1995;123:941-948.

-16 Panella M, Marchisio S, Di SF: Reducing clinical variations with clinical pathways: do pathways work? Int J Qual Health Care 2003; 15:509-521.

17 Rosborough D: Cardiac surgery in elderly patients: strategies to optimize outcomes. Crit Care Nurse 2006;26:24-31
18 Wicke C, Teichmann R, Holler T, Rehder F, Becker HD: Design and use of patient pathways in general surgery (in German). Chirurg 2004;75:907-915.

19 Balcom JH, Rattner DW, Warshaw AL, Chang Y, Fernandez-del-Castillo C: Tenyear experience with 733 pancreatic resections: changing indications, older patients, and decreasing length of hospitalization. Arch Surg 2001;136:391-398.

20 Basse L, Thorbol JE, Lossl K, Kehlet H: Colonic surgery with accelerated rehabilitation or conventional care. Dis Colon Rectum 2004;47:271-277.

-21 Delaney CP, Zutshi M, Senagore AJ, Remzi FH, Hammel J, Fazio VW: Prospective, randomized, controlled trial between a pathway of controlled rehabilitation with early ambulation and diet and traditional postoperative care after laparotomy and intestinal resection. Dis Colon Rectum 2003;46:851-859.

22 Hirao M, Tsujinaka T, Takeno A, Fujitani K, Kurata M: Patient-controlled dietary schedule improves clinical outcome after gastrectomy for gastric cancer. World J Surg 2005; 29:853-857.

23 Hirasaki S, Tanimizu M, Moriwaki T, Hyodo I, Shinji T, Koide N, Shiratori Y: Efficacy of clinical pathway for the management of mucosal gastric carcinoma treated with endoscopic submucosal dissection using an insulated-tip diathermic knife. Intern Med 2004; 43:1120-1125.

24 Kariv Y, Delaney CP, Senagore AJ, Manilich EA, Hammel JP, Church JM, Ravas J, Fazio VW: Clinical outcomes and cost analysis of a 'fast track' postoperative care pathway for ileal pouch-anal anastomosis: a case-control study. Dis Colon Rectum 2007;50:137-146.
Lemmens/van Zelm/Borel Rinkes/ van Hillegersberg/Kerkkamp 
-25 Kennedy EP, Rosato EL, Sauter PK, Rosenberg LM, Doria C, Marino IR, Chojnacki KA, Berger AC, Yeo CJ: Initiation of a critical pathway for pancreaticoduodenectomy at an academic institution - the first step in multidisciplinary team building. J Am Coll Surg 2007;204:917-923.

-26 Melbert RB, Kimmins MH, Isler JT, Billingham RP, Lawton D, Salvadalena G, Cortezzo M, Rowbotham R: Use of a critical pathway for colon resections. J Gastrointest Surg 2002;6:745-752.

-27 Porter GA, Pisters PW, Mansyur C, Bisanz A, Reyna K, Stanford P, Lee JE, Evans DB: Cost and utilization impact of a clinical pathway for patients undergoing pancreaticoduodenectomy. Ann Surg Oncol 2000;7: 484-489.

-28 Raue W, Haase O, Junghans T, Scharfenberg M, Muller JM, Schwenk W: 'Fast-track' multimodal rehabilitation program improves outcome after laparoscopic sigmoidectomy: a controlled prospective evaluation. Surg Endosc 2004;18:1463-1468.

-29 Stephen AE, Berger DL: Shortened length of stay and hospital cost reduction with implementation of an accelerated clinical care pathway after elective colon resection. Surgery $2003 ; 133: 277-282$.
30 Tan JJ, Foo AY, Cheong DM: Colorectal clinical pathways: a method of improving clinical outcome? Asian J Surg 2005;28:252-256.

-31 Wichmann MW, Roth M, Jauch KW, Bruns CJ: A prospective clinical feasibility study for multimodal 'fast track' rehabilitation in elective pancreatic cancer surgery. Rozhl Chir 2006;85:169-175.

-32 Basse L, Jacobsen DH, Billesbolle P, Kehlet $\mathrm{H}$ : Colostomy closure after Hartmann's procedure with fast-track rehabilitation. Dis Colon Rectum 2002;45:1661-1664.

33 Delaney CP, Fazio VW, Senagore AJ, Robinson B, Halverson AL, Remzi FH: 'Fast track' postoperative management protocol for patients with high co-morbidity undergoing complex abdominal and pelvic colorectal surgery. Br J Surg 2001;88:1533-1538.

34 Schwenk W, Hasse O, Raue W, Neudecker J, Muller JM: Establishing 'fast-track' colonic surgery in the clinical routine. Zentralbl Chir 2004;129:502-509.

-35 Schwenk W, Raue W, Bloch A, Haase O, Muller JM, Spies C: Accelerate postoperative recovery - fast-track rehabilitation in colonic surgery. Klinikarzt 2006;35:122-126.

36 Wichmann MW, Jauch KW: Fast track concepts and multimodal rehabilitation in colorectal surgery. Rozhl Chir 2005;84:163167.
37 Anthony MK, Hudson-Barr D: A patientcentered model of care for hospital discharge. Clin Nurs Res 2004;13:117-136.

38 Merriman ML: Pre-hospital discharge planning: empowering elderly patients through choice. Crit Care Nurs Q 2008;31:52-58.

$>39$ Anthony MK, Hudson-Barr DC: Successful patient discharge. A comprehensive model of facilitators and barriers. J Nurs Adm 1998; 28:48-55.

40 Edwards N: Doctors and managers: poor relationships may be damaging patients - what can be done? Qual Saf Health Care 2003; 12(suppl 1):i21-i24

41 International Agency for Research on Cancer. CANCERmondial. International Agency for Research on Cancer (http://www-dep. iarc.fr/; last accessed April 2008).

42 Campbell M, Fitzpatrick R, Haines A, Kinmonth AL, Sandercock P, Spiegelhalter D, Tyrer P: Framework for design and evaluation of complex interventions to improve health. BMJ 2000;321:694-696.

43 Medical Research Council: A Framework for Development and Evaluation of RCTs for Complex Interventions to Improve Health Care. London, MRC, 2000.

44 Medical Research Council: Cluster Randomised Trails: Methodological and Ethical Considerations. London, MRC, 2002. 